\title{
From Practitioner to Researcher: A Threshold Concept - A personal reflection on my own 'tug of war'
}

\author{
Sarah Elliott \\ University of Brighton, UK and Medway NHS Foundation Trust, UK \\ Angela Glynn \\ University of Brighton, UK \\ Jane Morris \\ University of Brighton, UK
}

\begin{abstract}
A threshold concept can be considered as a gateway, opening up a new way of thinking about something. In this paper, I share my personal journey and reflections as I embark upon a professional doctorate programme. I share my changing ontological and epistemological views as I undertake a paradigm shift moving from clinician to researcher. As a consequence of understanding a threshold concept, I will share my transformed worldview and the impact of this upon my doctoral studies.
\end{abstract}

Keywords: epistemology; ontology; paradigm shift; threshold concept

${ }^{*}$ Corresponding Author: Sarah Elliott, Physiotherapy Department, Medway Maritime Hospital, Gillingham Kent, UK ME7 5NY Email: sarah.elliott@medway.nhs.uk

Journal URL: http://e-learning.coventry.ac.uk/ojs/index.php/pblh

Elliott, S. with Glynn, A. and Morris, J. (2016) 'From practitioner to researcher: A threshold concept - A personal reflection on my own 'tug of war'. International Journal of Practice-based Learning in Health and Social Care, 4 (1),78-87. doi:10.18552/ijpblhsc.v4i1.203

(C) 2016 Sarah Elliott, Angela Glynn and Jane Morris. This Open Access article is distributed under the terms of the Creative Commons Attribution Non-Commercial License 4.0 International License (http://creativecommons.org/licenses/by-nc/4.0/), which permits unrestricted non-commercial use, distribution, and reproduction in any medium, provided the original work is properly cited.

NOTE: The reflection in this article, although personal, has been initiated through a formal course of study that necessitates recognition of supervisors as secondary authors. 


\section{Introduction}

In this article, I wish to share the personal journey that I have undertaken since embarking on a professional doctorate programme at a UK university during my transition from clinical practitioner working in the National Health Service (NHS) to researcher. The features of a threshold concept can be used to define transformative points in my development as a doctoral student. My doctorate is a phenomenological study which explores the experiences of practicebased learning within a seven-day model of working ${ }^{1}$. The aim of this study is to gain insight into, and understanding of, the lived experience of physiotherapy practice-based educators, and of physiotherapy students' encounters of seven-day working.

A threshold concept defined by Meyer and Land (2003) may be considered a gateway, opening up a new way of thinking about something. It represents a transformed way of understanding, or interpreting something without which the individual cannot progress (Meyer and Land 2003). As a consequence of comprehending a threshold concept, there may be a transformed worldview (Meyer and Land 2003). Land, Meyer, and Baillie (2010) describe the features of a threshold concept as relational, where, during the preliminal stage, the main feature is encountering troublesome knowledge, before moving on to the liminal stage. This is where ontological and epistemic shifts may occur which permit movement to the consequential post liminal stage where transformation may occur which is irreversible. I will draw on these features to discuss how I moved through the preliminal stage as I struggled to comprehend my identity as a researcher. This was followed by the liminal stage where I tussled with my ontological and epistemological stance. Finally, realisation that I had undergone a paradigm shift with consequences for me personally and on my doctoral studies emerged in the postliminal stage.

\section{The preliminal stage}

According to Stokes, King and Libarkin (2007), the first stage in acquiring a threshold concept involves entering a liminal space. This is a suspended state of partial understanding where individuals may encounter difficulties in understanding, or find that what they once thought was certain is now challenged in some way. Meyer and Land (2005) suggests that in this state of 'liminality', individuals will attempt to grasp new concepts and understandings that will ultimately transform how they think and practice, or how they perceive, apprehend, or experience particular phenomena within their discipline (Meyer and Land 2005).

In identifying my worldview as a novice researcher, I consider my multiple roles as a physiotherapist; as a clinician, facilitator and leader. I often adopt a different stance according to the situation, adopting a pragmatic approach in order to meet the demands and requirements of each role. This is demonstrated in Table 1.

\footnotetext{
1 "Seven day service provision is about equitable access, care and treatment, regardless of the day of the week. The level of service provided should ensure that the patient has a seamless pathway of care when accessing services no matter what day of the week" (NHS Improving Quality, 2013: 9).
} 
Table 1. The multiple roles I undertake as a pragmatic physiotherapist

\begin{tabular}{|c|c|c|c|c|c|}
\hline Role & Aim & Ontology & Epistemology & Methodology & Influences \\
\hline $\begin{array}{l}\text { Physiotherapist - } \\
\text { Clinician }\end{array}$ & $\begin{array}{ll}\text { - } & \text { Evidence based } \\
\text { practice } \\
\text { - Ensure excellent } \\
\text { patient } \\
\text { experience }\end{array}$ & $\begin{array}{ll} & \text { Realist } \\
\text { - } & \text { Critical Realist }\end{array}$ & $\begin{array}{ll}\text { - } & \text { Positivist } \\
\text { - } & \text { Post positivist }\end{array}$ & $\begin{array}{l}\text { Quantitative; RCTS, } \\
\text { case studies, Objective } \\
\text { measures }\end{array}$ & $\begin{array}{l}\text { Acceptance by medical model, standards } \\
\text { to achieve, guidelines to meet, objective } \\
\text { measures, need to measure success } \\
\text { - Patient satisfaction, standards of care, } \\
\text { effective treatment }\end{array}$ \\
\hline $\begin{array}{l}\text { Physiotherapy - } \\
\text { Manager }\end{array}$ & $\begin{array}{l}\text { Financial; } \\
\text { managing } \\
\text { budgets } \\
\text { - } \begin{array}{l}\text { Maintaining } \\
\text { productivity }\end{array} \\
\text { - } \begin{array}{l}\text { Cost effective } \\
\text { service }\end{array}\end{array}$ & - $\quad$ Realist & - $\quad$ Positivist & $\begin{array}{l}\text { Quantitative; facts and } \\
\text { figures }\end{array}$ & - $\quad$ Targets, financial constraints \\
\hline $\begin{array}{l}\text { Physiotherapy - } \\
\text { Practice based } \\
\text { educator }\end{array}$ & $\begin{array}{l}\text { - } \begin{array}{l}\text { Provision of high } \\
\text { standard of } \\
\text { student } \\
\text { placements }\end{array} \\
\text { - } \begin{array}{l}\text { Development of } \\
\text { junior staff }\end{array}\end{array}$ & - $\quad$ Critical Realist & - $\quad$ Post positivist & $\begin{array}{ll}\text { - } & \text { Mixed methods, student } \\
\text { and staff feedback } \\
\text { - } & \text { Rotation feedback } \\
\text { - } & \text { Achieving objectives }\end{array}$ & $\begin{array}{ll}\text { - } & \text { CSP / University standards } \\
\text { - } & \text { Appraisals }\end{array}$ \\
\hline $\begin{array}{l}\text { Physiotherapist - } \\
\text { Team Leader }\end{array}$ & $\begin{array}{l}\text { Involvement of } \\
\text { staff in service } \\
\text { development }\end{array}$ & - $\quad$ Critical Realist & - $\quad$ Post positivist & $\begin{array}{l}\text { Mixed methods, } \\
\text { reflections, evaluations, } \\
\text { surveys, audit }\end{array}$ & $\begin{array}{l}\text { Objective measures and standards, } \\
\text { guidelines, meeting criteria }\end{array}$ \\
\hline
\end{tabular}


In contrast, as a professional doctorate student, I believe each individual will have her/his own interpretation of experiences, and knowledge may be constructed from these social interactions. In my research journal, I reflected upon my own internal paradigm war by depicting it pictorially as a tug of a war (Figure 1). I felt I was being pulled one way by the demands of the NHS and another by my beliefs as a researcher. By contrast, as a pragmatic physiotherapist, I sat in the middle, with the scope to be pulled either way according to the need or demand of the research. I was in a state of liminality, tugged one way by my profession as a physiotherapist, and the other by my developing knowledge as a researcher. I was challenged by the way I think and practice as a physiotherapist and was not always willing to change the way in which I viewed the world, thus making it an uncomfortable place to be. It took me a long time and lots of grappling with philosophy before I moved forward as a researcher, with a clearer stance as explained in the next section.

Figure 1. My paradigm tug of war

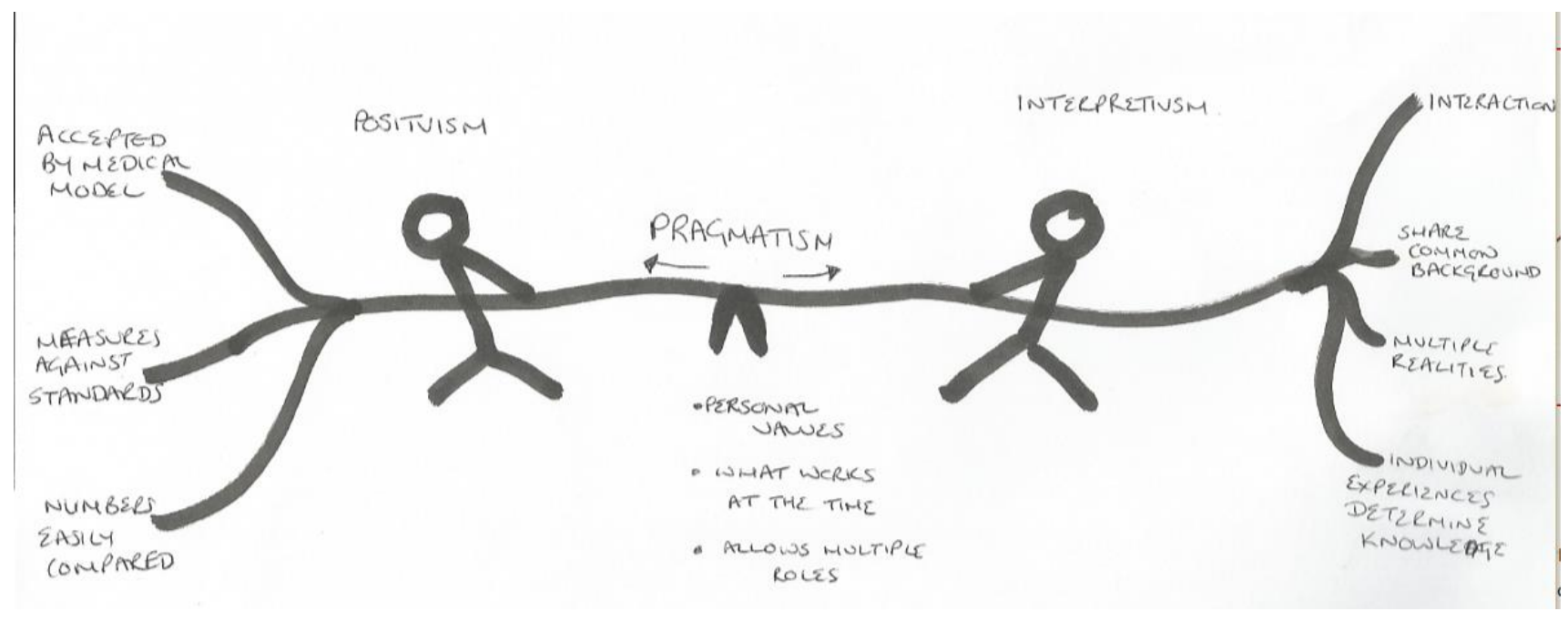

\section{The liminal stage}

A key feature of threshold concepts is that they are 'bounded' (Cousin 2006). That is, they help to define the scope or boundaries of a subject area (Smith 2006). A significant point in my research journal occurred as I reflected and analysed my stance in relation to my role as a clinician and that as a researcher. Figure 2 is an extract from my research journal.

From my reflections in my journal, it is evident that I was transforming and becoming a researching practitioner, rather than just a clinician. Life would never be the same again as described in the next section. 
Figure 2. Extract from research journal

The pull towards quantitative methods has been hard to resist. Not because I believe that is the right approach to take, but that I have been influenced by authority and the need for physiotherapy to be accepted in the medical profession. It seemed comfortable to keep drifting back to 'measuring' and 'proving' because that is what I have always done. However, in this instance as a researcher I want to explore the phenomena of seven day working from the perspectives of the educators and the students. I want to know what their experiences are - that way I will better understand the subject area. If we understand and interpret these experiences, it may provide important discoveries around this area and we know that the profession has to adopt seven day working. So rather than stick my head in the sand and assume it will be alright, I'm sticking mine above the parapet and asking 'what is your experience of practice based education in seven day working'. This might answer the concerns and questions of my peers, but more importantly it will provide me as a researcher the data I crave. Additionally, I have to look at myself as a researcher, not a clinician. Therefore I am 'free' to have my own worldview and philosophy as the only influence is myself and my beliefs which include believing that that no two experiences are the same and judgement/values/ truth are all relative to the individual.

Threshold concepts are both 'troublesome' and 'transformative' (Cousin 2006). I have battled emotionally with the concepts of epistemology and ontology, at times reluctant to leave the safe, secure position of a senior clinician, to that of a novice researcher, unsure of who I am and what I believe. Perkins (2006) explains that mastering threshold concepts often requires acquisition of knowledge that is troublesome, often the learner does not want to change or let go of their customary way of seeing things. It has taken time for me to understand that I can continue to be pragmatic about my clinical practice, but as a researcher I am free to be myself and that I need to allow my values and beliefs to be demonstrated and explained through my writing.

I used the analogy of a 'roller coaster ride' to depict my emotional battle pictorially in my research journal (Figure 3). This picture represents my paradigm shift and illustrates how my research question developed. It shows how I was initially troubled by the thought of altering my world-view, but then accepted that I could be an individual researcher with my own stance. Additional reflection about this roller coaster picture is included in Figure 4, which demonstrates that I am no longer feeing like a 'tug of war' as depicted in Figure 1. 
Figure 3. My philosophical journey and paradigm shift

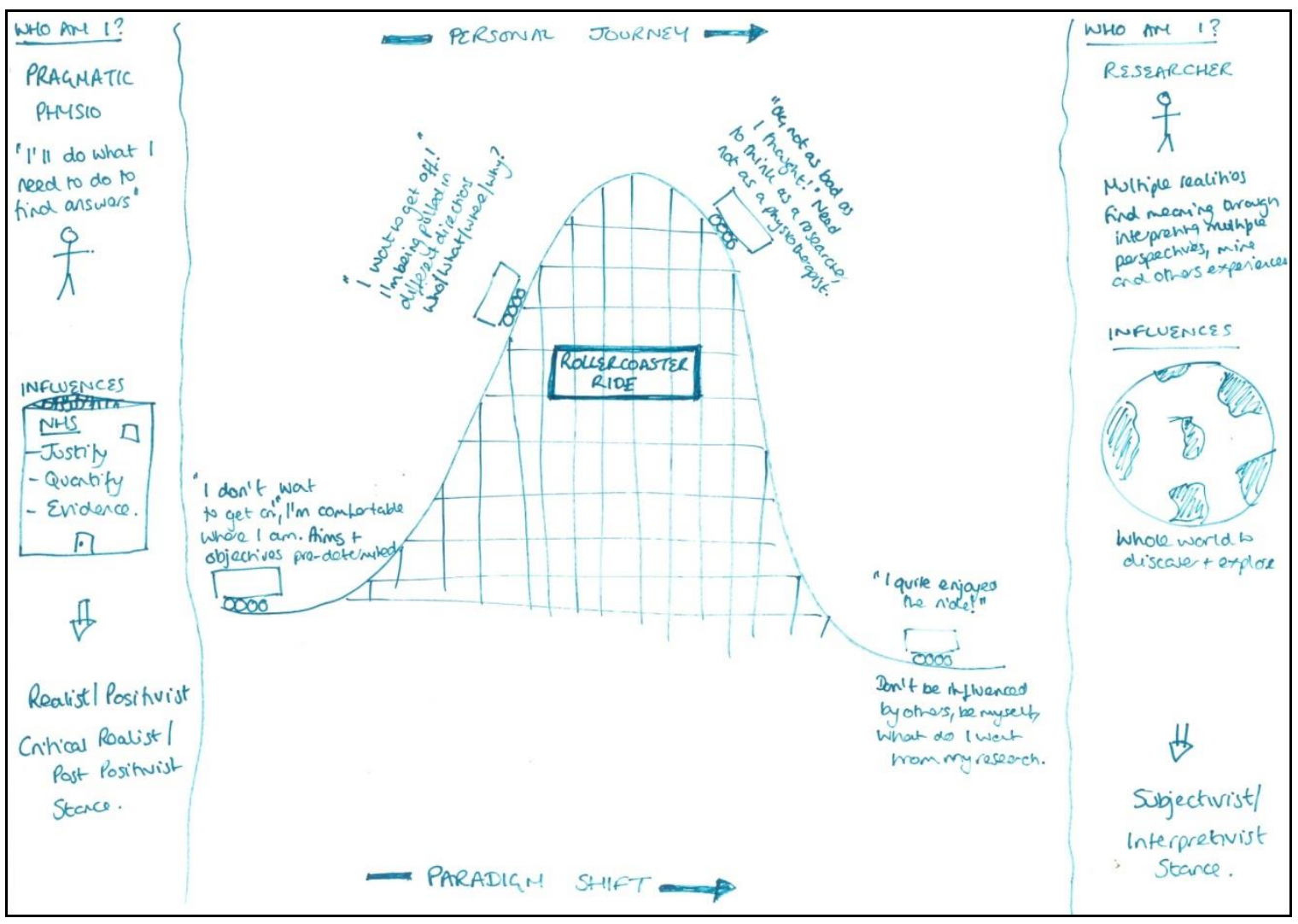

Figure 4. Extract from research journal relating to Figure 3

This drawing [Figure 3] really helped me to understand how I have to think as a researcher and can put aside the demands of a clinical role for the purpose of this research and that I am undertaking a personal journey of discovery, as well as a research study. No longer am I being pulled in different directions in a paradigm war but have made a paradigm shift which demonstrates my beliefs as a researcher within the interpretivist stance.

Once understood, a threshold concept changes the way in which an individual views the subject, and represents a transformed way of understanding, without which one cannot progress (Meyer and Land 2003). I felt at this stage that I had made a breakthrough and was able to continue on my research journey.

Threshold concepts are probably 'irreversible', and are unlikely to be forgotten (Meyer and Land, 2003). The doctoral process has changed me as a person and as a professional. Nothing is straight forward anymore, I am more analytical and I never take anything on face value now. My work colleagues have commented that I am no longer able to give a straight answer to a question, rather throwing questions back at them so they can explore the problem. Another situation I can recall was recorded in my research journal, Figure 5. 
Figure 5. Extract from research journal - Life will never be the same!

At 6am this morning, whilst swimming in the local pool, another
swimmer challenged whether I was quick enough to be swimming in
the fast lane, my response; 'what is your understanding and
interpretation of the term fast?' I'll never be the same again.
I am now beginning to see this change in myself. As an individual I
am becoming more comfortable and confident with the new me and
can begin to see how I have grown during this process and that it is
impacting on my whole life.

\section{Post liminal stage}

Threshold concepts, once learned, are likely to bring together different aspects of the subject that previously did not appear, to the student, to be related (Meyer and Land 2005). That is, they are 'integrated' (Meyer and Land 2005). Mastery of a threshold concept often allows the learner to make connections that were hitherto hidden from view.

It has been evident that whilst developing my research question, my own internal paradigm war contributed as I wrote the research question, phrased my research objectives and selected the methodology. Table 2 shows the development of my research question. At the time, I didn't realise that my developing philosophical stance had such a direct impact on my research question; it was hidden from immediate view. It is only now, as I reflect back on my journey, I can see how it affected my thinking and writing.

Table 2. The development of my research question and myself from a pragmatic physiotherapist to a researcher with an interpretivist approach

\begin{tabular}{|c|c|c|c|}
\hline & Assignment 1 & Assignment 2 & Assignment 3 \\
\hline $\begin{array}{l}\text { Research } \\
\text { question }\end{array}$ & $\begin{array}{l}\text { A team supervision } \\
\text { model: Is this a viable, } \\
\text { effective and } \\
\text { sustainable approach } \\
\text { to supporting } \\
\text { physiotherapy students } \\
\text { in clinical education } \\
\text { across seven day } \\
\text { working }\end{array}$ & $\begin{array}{l}\text { How can the development of a } \\
\text { team supervision model affect } \\
\text { physiotherapy clinical education } \\
\text { across seven day working? }\end{array}$ & $\begin{array}{l}\text { What are the experiences } \\
\text { of practice-based learning } \\
\text { within a seven day model } \\
\text { of working for practice- } \\
\text { based educators and } \\
\text { physiotherapy students? }\end{array}$ \\
\hline $\begin{array}{l}\text { Philosophical } \\
\text { stance }\end{array}$ & $\begin{array}{l}\text { Realist / positivist } \\
\text { approach - looking for } \\
\text { a practical solution to a } \\
\text { problem } \\
\text { 'Prove' } \\
\text { 'Justify' }\end{array}$ & $\begin{array}{l}\text { Pragmatic approach - multiple } \\
\text { roles, action orientated } \\
\text { Manager- realist / positivist } \\
\text { approach - quantitative data } \\
\text { Clinician - critical realist / post } \\
\text { positivist approach as } \\
\text { concerned about people } \\
\text { Educator - subjectivist / } \\
\text { interpretivist approach as } \\
\text { exploring experiences }\end{array}$ & $\begin{array}{l}\text { Subjectivist / interpretivist } \\
\text { approach } \\
\text { My beliefs as a } \\
\text { researcher; } \\
\text { No two experiences are } \\
\text { the same } \\
\text { Judgement/ values/ truth } \\
\text { are all relative to the } \\
\text { individual }\end{array}$ \\
\hline Methodology & $\begin{array}{l}\text { Quantitative methods - } \\
\text { facts and figures }\end{array}$ & $\begin{array}{l}\text { Action Research - looking to } \\
\text { solve a problem in the real } \\
\text { world. Allows a mixed method } \\
\text { approach to match multiple } \\
\text { roles. } \\
\text { Manager - facts and figures; } \\
\text { productivity / cost } \\
\text { Clinician - productivity, patient- } \\
\text { centred care } \\
\text { Educator - experiences and } \\
\text { evaluations }\end{array}$ & $\begin{array}{l}\text { Phenomenology - as a } \\
\text { researcher I want to } \\
\text { explore and discover } \\
\text { experiences and interpret } \\
\text { their meanings }\end{array}$ \\
\hline
\end{tabular}


Figure 6. This diagram demonstrates my understanding of my philosophical stance within research and an increased confidence with terminology and how the process links together.

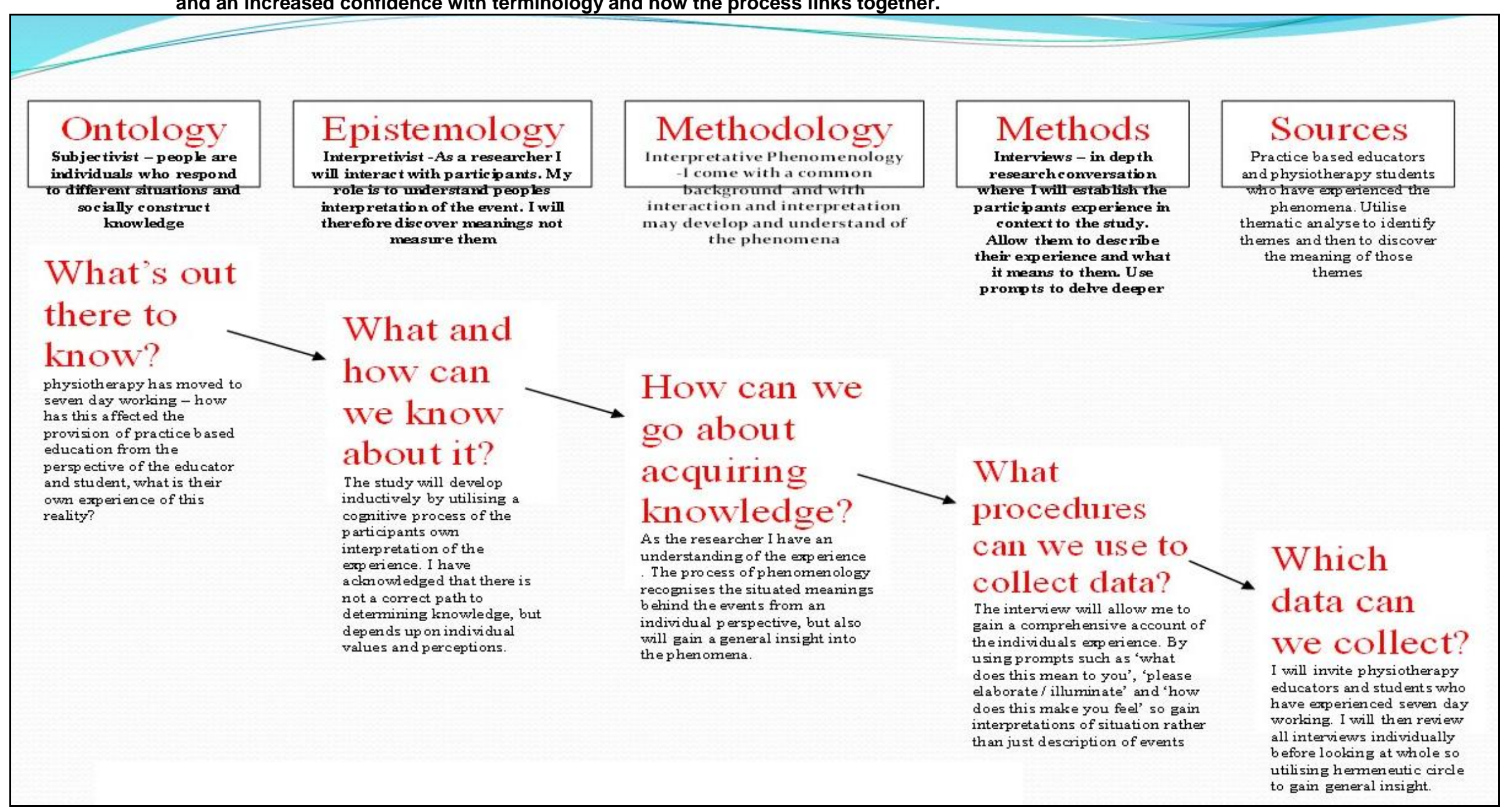




\section{A discursive process}

Meyer and Land (2003) suggest that the crossing of a threshold is a 'discursive' process in that it incorporates an enhanced and extended use of language, and this is true of me. At the start of the doctorate, words such as ontology and epistemology were new to me, as were positivism and interpretivism. I am now able to use these terms with greater knowledge and confidence, and rationalise their impact on my research journey. Figure 6, a PowerPoint ${ }^{\mathrm{TM}}$ slide used to explain my research at a student conference, demonstrates my understanding of my philosophical stance with research and an increased confidence with terminology and how the process links together.

\section{Conclusion}

The notion of threshold concepts and their potential to characterise ways of thinking and practising within a discipline has emerged as a useful and effective means of gaining insight into students' conceptual understandings (Stokes, King, and Libarkin 2007). I have learnt that adjusting one's worldview is very challenging. It is a journey of reflection, self-analysis, questioning, self-doubt, lack of confidence in my ability as a doctoral student, and moving back and forth between my old comfortable lens and my new lens. It is only now I can look back and feel comfortable and familiar with my new worldview as a researcher on a doctoral programme and take my studies forward with confidence. I have a new understanding of who I am, how I see and feel. I was not aware at the time that I crossed a conceptual threshold and I have no doubt I will revisit, and pass back and forth on many more occasions according to the situation, and $I$ as continue to grow and change as a researcher. 


\section{Acknowledgements}

I would like to extend my thanks to my research supervisors who have supported me, and continue to support me, on my research journey.

\section{References}

Cousin, G. (2006) 'An introduction to threshold concepts'. Planet 17, 4-5. [online] available from http://www.tandfonline.com/doi/abs/10.11120/plan.2006.00170004 doi:10.11120/plan.2006.00170004

Land, R., Meyer, J.H.F., and Baillie, C. (2010) 'Editors' Preface: Threshold Concepts and Transformational Learning'. in Threshold concepts and transformational learning. ed by Meyer, J. H.F., Land, R., \& Baillie, C. Rotterdam: Sense Publishers, ix-xlii

Meyer, J.H.F and Land, R. (2005) Threshold concepts and troublesome knowledge (2): Epistemological considerations and a conceptual framework for teaching and learning. Higher Education, 49 (3), 373-388 doi: 10.1007/s10734-004-6779-5

Meyer, J.H.F and Land, R. (2003) 'Threshold concepts and troublesome knowledge :linkages to ways of thinking and practising'. in Improving student learning- theory and practice ten years on. ed by Rust, C. Oxford: Oxford Centre for Staff and Learning Development (OSCLD), 412-424

NHS Improving Quality (2013) NHS Services- open seven days a week: everyday counts. [online] available from http://www.nhsiq.nhs.uk/8763.aspx

Perkins,D (2006) 'Construction and troublesome knowledge'. in Overcoming barriers to student understanding: threshold concepts and troublesome knowledge. ed by Meyer, J.H.F and Land, R. London and New York: Routledge, Taylor and Francis, 33-47

Smith, J. (2006) 'Lost in translation; staff and students negotiating liminal spaces'. in Proceedings of the SEDA spring conference, Advancing Evidence-Informed Practice in HE Learning, Teaching and Educational Development'. held 8-9 June 2006, Liverpool. [online] available from http://seda.ac.uk/confs/liv06/abstracts/15 Smith.pdf

Stokes, A. King, H., and Libarkin, J.C. (2007) 'Research in science education:threshold concepts'. Journal of Geoscience Education, 5 (55), 434-438 